\title{
ESTIMATION OF GREENHOUSE GAS EMISSIONS FROM LANDFILLS: APPLICATION TO THE AKROTIRI LANDFILL SITE (CHANIA, GREECE)
}

\author{
E. CHALVATZAKI \\ M. LAZARIDIS ${ }^{*}$
}

\author{
Department of Environmental Engineering \\ Technical University of Crete \\ Chania-73100, Crete-Greece
}

Received: 01/12/09

Accepted: 11/02/10 *to whom all correspondence should be addressed: e-mail: lazaridi@mred.tuc.gr

\begin{abstract}
Landfilling is one of the most common ways of municipal solid waste (MSW) disposal in developing countries. Air pollutants emitted from landfills contributes to the emission in the atmosphere of greenhouse gases and cause serious problems to the human health. Methane emission from landfill is serious environmental global concern as it accounts for approximately 15 percentages of current greenhouse gas emissions. The current study was focused on the determination of air emissions from the Akrotiri landfill site which is located at the Akrotiri area (Chania, Greece). The models used are the triangular model, the stoichiometric model and LandGEM model. These models are used to estimate the total landfill gas production from a given amount of waste. The models differ on their scientific approach for the quantification on emissions, their complexity and input data requirements. The LandGEM model was selected for the determination of more representative assessed landfill gas emission rates. The maximum biogas production rate by the LandGEM model was calculated to be $1.64 \times 10^{3} \mathrm{Mg}$ $\mathrm{yr}^{-1}$ and was observed during the year 2008 for the A phase of the landfill, while for the B phase the maximum biogas production rate was $2.70 \times 10^{3} \mathrm{Mg} \mathrm{yr}^{-1}$ and was observed during 2014.
\end{abstract}

KEYWORDS: methane, LandGEM, stoichiometric, triangular.

\section{INTRODUCTION}

Municipal solid waste is a significant contributor to greenhouse gas emissions through decomposition and life-cycle activities processes. The majority of these emissions are a result of landfilling, which remains the primary waste disposal strategy internationally (Lou, 2009). In particular the disposal of waste in landfills generates methane that has high global warming potential. Effective mitigation of greenhouse gas emissions is important and could provide environmental benefits and sustainable development, as well as reduce adverse impacts on public health (Papageorgiou, 2009).

In the last decades the greenhouse gases produced by human activities have been predominating over those of natural origin (Hansen, 2004). The waste sector is a significant contributor to greenhouse gas (GHG) emissions accountable for approximately $5 \%$ of the global greenhouse budget (IPCC, 2006). This 5\% consist of methane $\left(\mathrm{CH}_{4}\right)$ emission from anaerobic decomposition of solid waste and carbon dioxide $\left(\mathrm{CO}_{2}\right)$ from wastewater decomposition (IPCC, 2006).

Landfills are among the nation's largest emitters of methane, a key greenhouse gas, and there is considerable interest in quantifying the surficial methane emissions from landfills (Mackie, 2009). The greenhouse gases emissions related to landfilling are mainly due to methane $\left(\mathrm{CH}_{4}\right)$ and carbon dioxide $\left(\mathrm{CO}_{2}\right)$ present in the biogas produced by anaerobic bacteria using as carbon source the biodegradable carbon contained in the waste (IPCC, 
2007a; Gardner et al., 1993). European research has identified that landfill gas is composed of 140 trace components of which 90 were common to all studies landfill sites (Parker et al.,2002). NMOCs_(non-methane organic compounds) usually make up also less than $1 \%$ of landfill gas. Methane is regarded as one of the most important GHGs because its global warming potential has been estimated to be more than 20 times of that of carbon dioxide and atmospheric methane concentration has been increasing in the range of $1-2 \%$ per year (IPCC, 2007a).

The atmospheric concentration of methane has increased by $151 \%$ since 1750 and its concentration continues to increase (IPCC, 2007a). Furthermore, methane is an explosive gas in concentrations between 5 and 15 percent in air. Although there is no immediate danger from the methane emitted in atmosphere from landfills, it could accumulate inside the landfill mass, thus increasing its concentration. There have been several fire reports due to methane emissions in landfills (Christensen et al., 1998; Boltze and De Freitas, 1997; Jones and Nedwell, 1990; Kjeldsen and Fischer, 1995).

There are two life stages in a landfill, its operating stage, where municipal solid waste (MSW) is being disposed of, and its closed stage, where storage capacity is reached. Operating landfills emits more $\mathrm{CH}_{4}$ than closed landfills since the major part of degradation occurs in the first few years following disposal with decreasing emission rates with time after closure (Fourie and Morris, 2004; Humer and Lechner, 1999a). Following closure, a landfill continues to emit GHG, possibly for several hundreds of years (Borjesson et al., 2004).

Globally, efforts are being made to control greenhouse gas (GHG) emission from various sources, waste sector is one of them. The Kyoto protocol in Europe foresees the reduction of the principal anthropogenic emissions of the gases responsible for altering the natural greenhouse effect. In particular, in the period 2008-2012, the industrialized countries should reduce the emissions by $5 \%$ in respect to the 1990 values. So, reducing the GHG emission from landfills contributes to stabilizing GHG concentrations in the atmosphere at a level that would prevent the dangerous anthropogenic interference with the climate system.

Global greenhouse gas emissions in 2005 from waste based on reported emissions from national inventories and national communications, and (for non-reporting countries) on 1996 inventory guidelines and extrapolations was $750 \mathrm{Mt} \mathrm{CO}_{2}$-eq (US EPA, 2006) while based on 2006 inventory guidelines and BAU projection was $520 \mathrm{Mt} \mathrm{CO}_{2}$-eq (Monni et al., 2006). The US EPA (2006) study collected data from national inventories and projections reported to the United Nations Framework Convention on Climate Change (UNFCCC) and supplemented data gaps with estimates and extrapolations based on IPCC default data and simple mass balance calculations using the 1996 IPCC Tier 1 methodology for landfill $\mathrm{CH}_{4}$. Monni et al., (2006) calculated a time series for landfill CH4 using the first-order decay (FOD) methodology and default data in the 2006 IPCC Guidelines, taking into account the time lag in landfill emissions compared to year of disposal (IPPC 2007b).

Due to the importance of GHG emissions from landfills, in the current study a methodology is adopted to calculate the total landfill gas production from landfills using different emission models. The methodology is applied to a landfill in the area of Chania, Greece.

\section{MATERIALS AND METHODS}

\subsection{Description of the Akrotiri landfill site}

The methodology has been applied to a local landfill which belongs to the Chania municipality on the island of the Crete (Greece). The Akrotiri landfill is located in the northeast part of the prefecture of Chania and east of the city of Chania. The landfill consists of 2 phases. The first phase (rehabilitated cell) began the operation during 2003 and closed on $13^{\text {th }}$ May 2007 and had a capacity of 440.000 cubic meters. The second phase (active cell) started the operation on $14^{\text {th }}$ May 2007 and is foreseen to operate until 2013. The capacity of the phase B is 660.000 cubic meters. The annual acceptance rate of solid waste was $80,000 \mathrm{tn}^{-1} \mathrm{r}^{-1}$ for the $\mathrm{A}$ phase of the landfill and $85,000 \mathrm{tn}^{-1} \mathrm{r}^{-1}$ for the phase B of the landfill. The waste in the landfill is composed from bio waste $(40.27 \%)$, paper (16.39\%), plastic (15.26\%) and slow-degraded 
materials (such as wood, plastic, etc) (11.98\%) as derived from measurements for the waste composition at the Akrotiri site.

\subsection{Description of the gas emission rate models}

In the current study three different emission models for gas generated from landfills have been incorporated. The models used are the triangular model, the stoichiometric model and LandGEM model. These models are used to estimate the total landfill gas production from a given amount of waste. The models differ on their scientific approach for the quantification on emissions, their complexity and input data requirements. A short description of them is presented.

\subsubsection{The triangular model}

In the triangular model the organic materials in landfill are divided into two categories: materials that degrade rapidly (from 3 months to 5 years) and materials that degrade slowly (up to 25 years). The degradation rate usually reaches the maximum within the first two years and then gradually reduced. The annual rates of degradation for fast and slow biodegradable material are based on a triangular model. The maximum rate of production occurs during the first and fifth year from the beginning of production for the rapidly and slowly decomposable materials respectively. The biogas production is assumed that begins at the end of the first complete year of the landfill operation. The total quantity of biogas produced from municipal solid waste (MSW) placed first time of operation can be expressed with the following formula:

Total biogas produced $\left(\mathrm{m}^{3} \mathrm{~kg}^{-1}\right)=1 / 2$ (years of gas production $) \times($ peak biogas production rate $\left.\left(\mathrm{m}^{3} \mathrm{~kg}^{-1} \mathrm{yr}^{-1}\right)\right)$.

However an important factor which limits the use of the model is the moisture content. Usually in landfills the available moisture is insufficient to perform complete conversion of biodegradable organic materials into municipal solid waste (MSW). The best moisture content for the conversion of biodegradable organic fraction is in the range between $50-60 \%$. However, in many landfills, the moisture is not uniformly distributed. When the moisture content is low, the biogas production curve is more linear and extends to longer time periods (Halvadakis, 1983).

\subsubsection{The stoichiometric model}

The stoichiometric model is based on a global stoichiometric reaction, in which the reactants in the waste are represented by an empirical chemical formula, and the products include methane and carbon dioxide. The biodegradation processes of the organic biodegradable fraction to form landfill gas can be described by the global stoichiometric reaction (Tchobanoglous et al., 1993)

$\mathrm{C}_{\mathrm{a}} \mathrm{H}_{\mathrm{b}} \mathrm{O}_{\mathrm{c}} \mathrm{N}_{\mathrm{d}}+\mathrm{n} \mathrm{H}_{2} \mathrm{O} \rightarrow x \mathrm{CH}_{4}+\mathrm{y} \mathrm{CO} \mathrm{CO}_{2}+\mathrm{w} \mathrm{NH}_{3}+\mathrm{z} \mathrm{C}_{5} \mathrm{H}_{7} \mathrm{O}_{2} \mathrm{~N}+$ energy

One limitation of the model is associated with the stoichiometric estimates of waste fractions which are not biodegradable (lignin, plastics), the moisture limitations and also toxins some fraction of the waste which is not accessible (e.g. plastic bags).

\subsubsection{The LandGEM emission model}

The LandGEM (landfill gas emissions model) is an easy to use automated tool to quantify air emissions from landfills. It is developed by the Control Center technology of the American Environmental Protection Agency (US E.P.A). The methodology for the estimation of gaseous emissions using the model is based on a simple degradation equation. The model determines the mass of methane generated using the methane generation capacity and the mass of waste deposited. The LandGEM emission methodology can be described mathematically by:

$\mathrm{Q}_{\mathrm{CH} 4}=\sum_{i=1}^{n} \sum_{j=0.1}^{1} k L_{0}\left(\frac{M_{i}}{10}\right)\left(e^{-k t}\right)$

where $\mathrm{Q}_{\mathrm{CH} 4}$ is the annual methane generation in the year of calculation $\left(\mathrm{m}^{3} \mathrm{yr}^{-1}\right)$, i the yearly time increment, $\mathrm{n}$ is the difference: (year of the calculation)-(initial year of waste acceptance), $\mathrm{j}$ the 0.1 year time increment, $\mathrm{k}$ is the methane generation constant $\left(\mathrm{yr}^{-1}\right), \mathrm{L}_{0}$ is the potential 
methane generation capacity $\left(\mathrm{m}^{3} \mathrm{Mg}^{-1}\right), \mathrm{M}_{\mathrm{i}}$ is the mass of waste in the $\mathrm{i}^{\text {th }}$ year $(\mathrm{Mg}), \mathrm{t}_{\mathrm{i}, \mathrm{j}}$ is the age of the $j^{\text {th }}$ section of waste $M_{i}$ accepted in the $i^{\text {th }}$ year (decimal years).

The model assumes that $\mathrm{CO}_{2}$ emissions are the same as $\mathrm{CH}_{4}$ emissions and that landfill gas emissions are twice the $\mathrm{CH}_{4}$ emissions. The annual emissions $\left(\mathrm{Q}_{\mathrm{c}}\right)$ for each $\mathrm{VOC},\left(\mathrm{kg} \mathrm{yr}^{-1}\right)$, is computed using the equation:

$\mathrm{Q}_{c}=\left(\mathrm{Q}_{\mathrm{m}} \times \mathrm{C}_{\mathrm{c}} \times \mathrm{m}_{\mathrm{c}}\right) /\left(\left(1 \times 10^{6}\right) \times(22.41)\right)$

where $Q_{m}$ is the methane generation rate $\left(\mathrm{m}^{3} \mathrm{yr}^{-1}\right), \mathrm{C}_{\mathrm{c}}$ is the concentration of compound $\mathrm{c}$ (ppmV), $\mathrm{m}_{\mathrm{c}}$ is the molecular weight of compound $\mathrm{c}\left(\mathrm{kg} \mathrm{kg}^{-1} \mathrm{~kg}^{-1}\right), 22.41$ is the standard volume of an ideal gas at $1 \mathrm{Atm}\left(\mathrm{m}^{3} \mathrm{~kg}^{-1} \mathrm{~mol}^{-1}\right)$ and $1 \times 10^{6}$ is a conversion factor (ppmV) (Paraskaki and Lazaridis, 2005).

The required inputs for estimating the amount of generated landfill gas are the design capacity of the landfill, the annual acceptance rate, the landfill gas generation constant $k$, the landfill gas generation potential $L_{0}$ and the number of year of waste acceptance. Default values for $k$ and $L_{0}$ can be used or site-specific values can be introduced (US EPA, 2005).

In the current application the methane generation rate $\mathrm{k}$ is set equal to $0.02 \mathrm{yr}^{-1}$ and is determined by the equation (US EPA, 2004):

$\mathrm{k}=3.2 \times 10^{-5}$ (annual average precipitation) $+0.01=3.2 \times 10^{-5} \times 371+0.01=0.02 \mathrm{yr}^{-1}$

where, the annual average precipitation is determined from meteorological data at the study area.

Furthermore, the potential methane generation capacity $L_{0}$ is equal $100 \mathrm{~m}^{3} \mathrm{Mg}^{-1}$ which corresponds to the conditions at the Akrotiri landfill, the NMOC concentration is equal to 2400 ppmV (as hexane) and the methane content is equal to $50 \%$.

\section{RESULTS}

Figures 1-2 show the annual landfill gas production rates provided by the LandGEM, the triangular and the stoichiometric models for the landfill A and B phases respectively. Each model makes different assumptions and using different input data. The difference between modelled and the measured landfill gas emission is a result of unknown parameters. Such parameters include the extent of aerobic and anaerobic decomposition, nutrient limitations, micro-organism inhibition because of waste-toxicity, physico-chemical interactions and other conditions for bacteria cell synthesis. Consequently the LandGEM model is selected for the determination of more representative assessed landfill gas emission rates since it is the most reliable model for the quantification of the emission rates and provides the most conservative and proximate estimates (Paraskaki and Lazaridis, 2005).

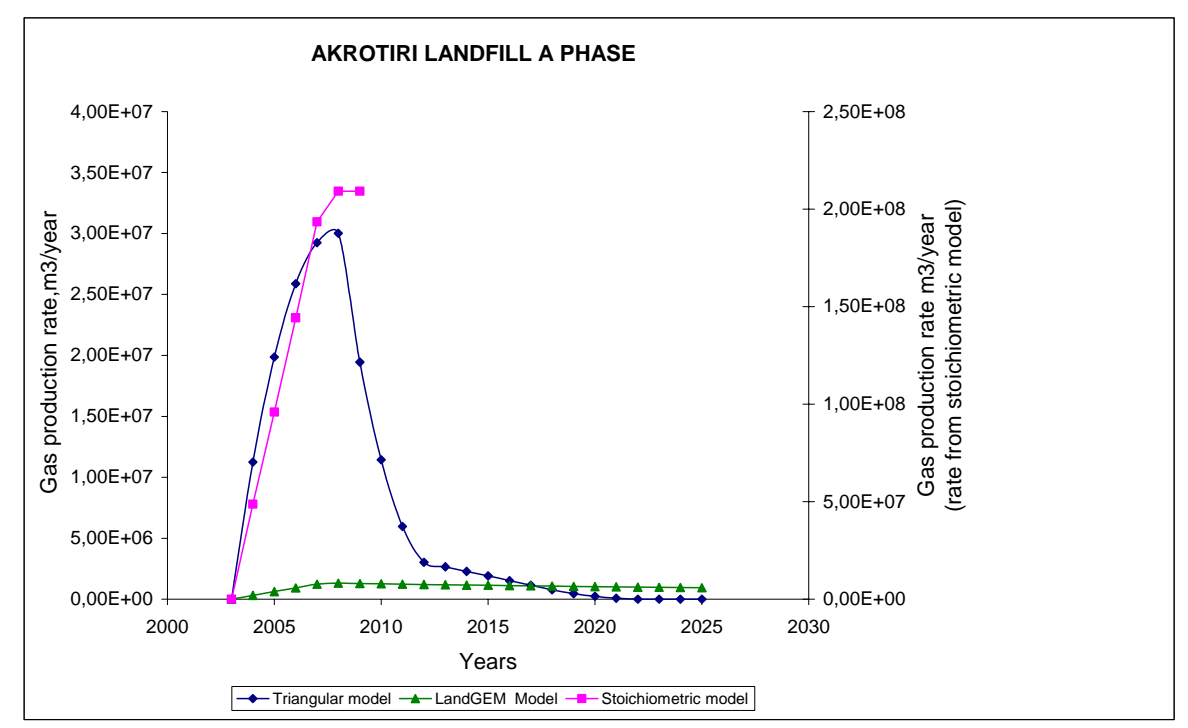

Figure 1. Annual landfill gas production rates $\left(\mathrm{m}^{3} \mathrm{yr}^{-1}\right)$ provided by the LandGEM, the triangular and the stoichiometric models for the Akrotiri landfill A phase (2003-2007) 
Figures 3-4 show the annual emission rate of biogas, $\mathrm{CH}_{4}$ and $\mathrm{CO}_{2}$ production for landfill $\mathrm{A}$ and $B$ phase respectively in accordance with the LandGEM model. The maximum biogas production rate is $1.64 \times 10^{3} \mathrm{Mg} \mathrm{yr}^{-1}$ and is observed during the year 2008 for the landfill $\mathrm{A}$ phase, while for the $\mathrm{B}$ phase the maximum biogas production rate is $2.70 \times 10^{3} \mathrm{Mg} \mathrm{yr}^{-1}$ and is observed during 2014. The maximum emission rate of $\mathrm{CH}_{4}$ is $4.37 \times 10^{2} \mathrm{Mg} \mathrm{yr}^{-1}$ and $1.20 \times$ $10^{3} \mathrm{Mg} \mathrm{yr}^{-1} \mathrm{CO}_{2}$ for the landfill $A$ phase, while for the landfill $B$ phase the maximum emission rate of $\mathrm{CH}_{4}$ is $7.22 \times 10^{2} \mathrm{Mg} \mathrm{yr}^{-1}$ and $1.98 \times 10^{3} \mathrm{Mg} \mathrm{yr}^{-1}$ for $\mathrm{CO}_{2}$. The years 2008 and 2014 for landfill $A$ and $B$ phase respectively corresponds to the closure year of the landfill which means that at this year a significant risk for the human population could be present (Ruston 2003). Methane is 21 times more efficient at trapping heat than carbon dioxide $\left(\mathrm{CO}_{2}\right)$ contributing crucially to global heating. It is calculated that $3.8 \%$ of the United States global warming potential arises from methane emissions from landfills (US EPA; 1995; Tagaris et al., 2003; Akolkar et al., 2008).

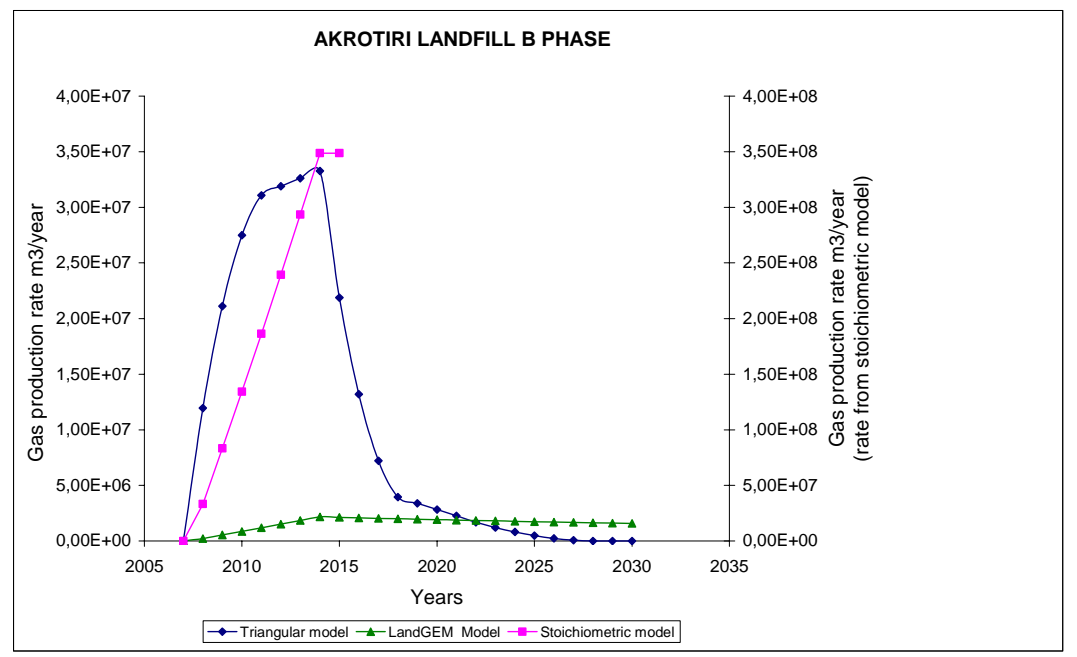

Figure 2. Annual landfill gas production rates $\left(\mathrm{m}^{3} \mathrm{yr}^{-1}\right)$ provided by the LandGEM, the triangular and the stoichiometric models for the Akrotiri landfill B phase (2007-2013)

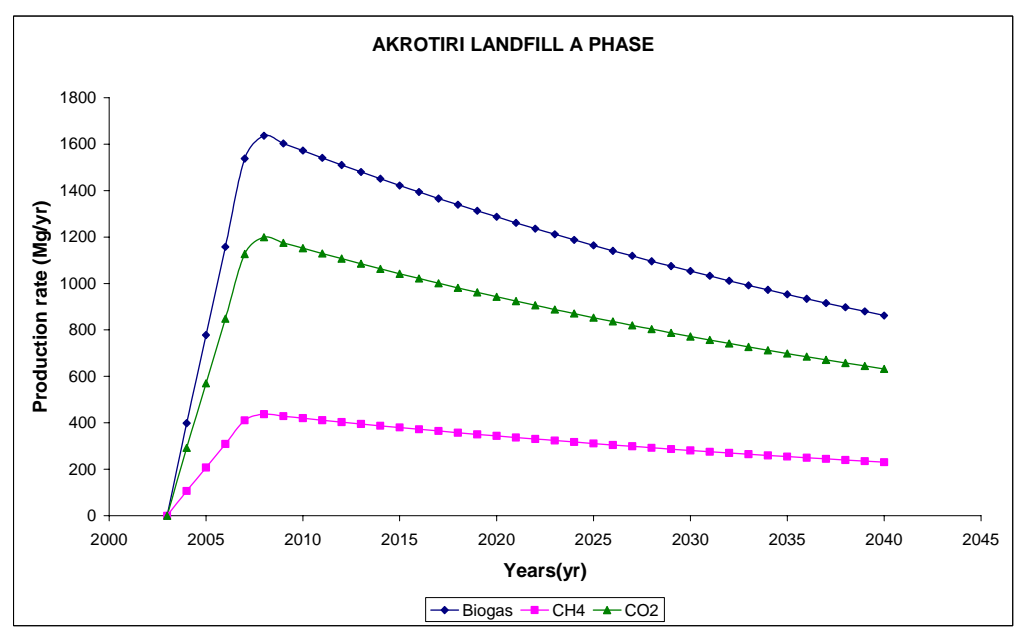

Figure 3. Annual emission rates $\left(\mathrm{Mg} \mathrm{yr}^{-1}\right)$ of biogas, $\mathrm{CH}_{4}$ and $\mathrm{CO}_{2}$ for the Akrotiri landfill $\mathrm{A}$ phase (2003-2007) 


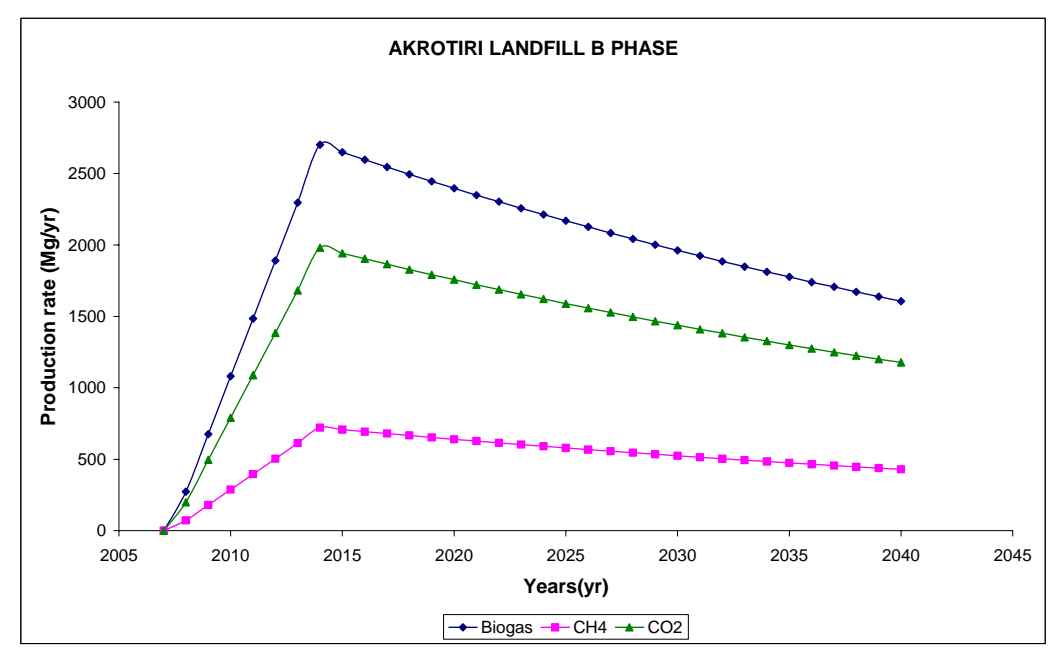

Figure 4. Annual emission rates $\left(\mathrm{Mg} \mathrm{yr}^{-1}\right)$ of biogas, $\mathrm{CH}_{4}$ and $\mathrm{CO}_{2}$ for the Akrotiri landfill $\mathrm{B}$ phase (2007-2013)

Figures 5-6 present the annual emission rates of $\mathrm{CO}, \mathrm{H}_{2} \mathrm{~S}$, benzene and vinyl chloride for the landfill $A$ and $B$ phases respectively. The maximum emission rate of $C O$ is $2.14 \times 10^{-1} \mathrm{Mg}$ $\mathrm{yr}^{-1}$ and $6.68 \times 10^{-2} \mathrm{Mg} \mathrm{yr}^{-1}$ for $\mathrm{H}_{2} \mathrm{~S}$ for the landfill $A$ phase, while for the landfill $B$ phase the maximum emission rate of $\mathrm{CO}$ is $3.53 \times 10^{-1} \mathrm{Mg} \mathrm{yr}^{-1}$ and $1.10 \times 10^{-1} \mathrm{Mg} \mathrm{yr}^{-1}$ for $\mathrm{H}_{2} \mathrm{~S}$. The maximum emission rate of benzene is $4.68 \times 10^{-2} \mathrm{Mg} \mathrm{yr}^{-1}$ and $2.49 \times 10^{-2} \mathrm{Mg} \mathrm{yr}^{-1}$ for vinyl chloride for the landfill $A$ phase, while for the landfill $B$ phase the maximum emission rate of benzene is $7.73 \times 10^{-2} \mathrm{Mg} \mathrm{yr}^{-1}$ and $4.11 \times 10^{-2} \mathrm{Mg} \mathrm{yr}^{-1}$ for vinyl chloride. It should be said that vinyl chloride is volatile component (the $73.4 \%$ of the mass is in the gas phase) while the benzene in percentage $80.3 \%$ it is found absorbed in the soil. This particularity of components has important impact on how these chemicals behave and moved out of the landfill (Lin et al., 1995).

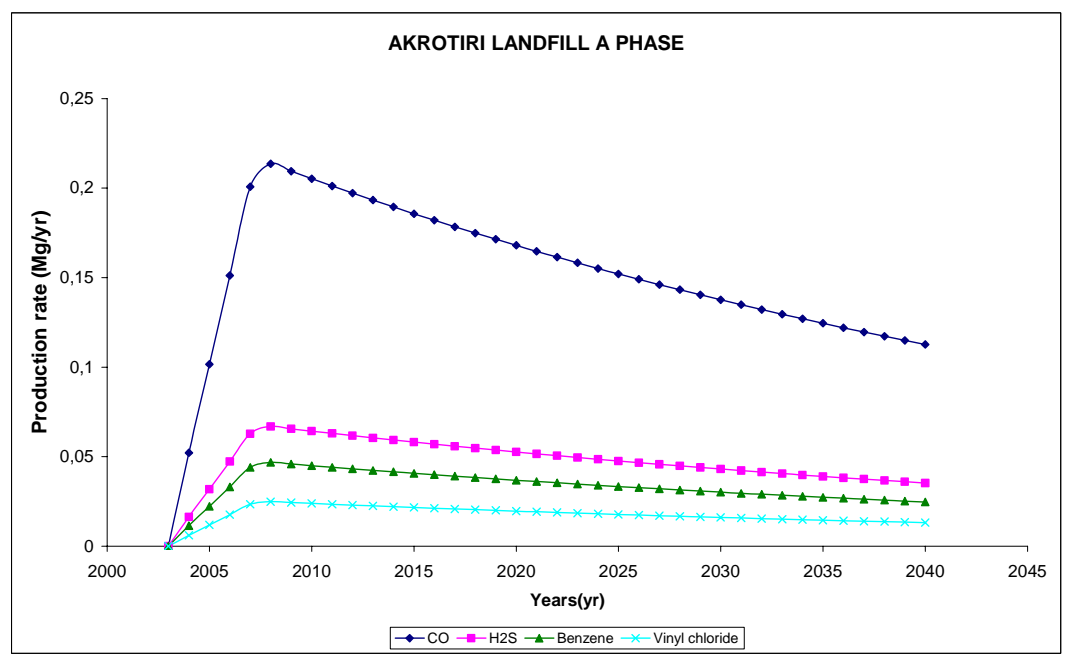

Figure 5. Annual emission rates $\left(\mathrm{Mg} \mathrm{yr}^{-1}\right)$ of $\mathrm{CO}, \mathrm{H}_{2} \mathrm{~S}$, benzene and vinyl chloride for the Akrotiri landfill A phase (2003-2007) 


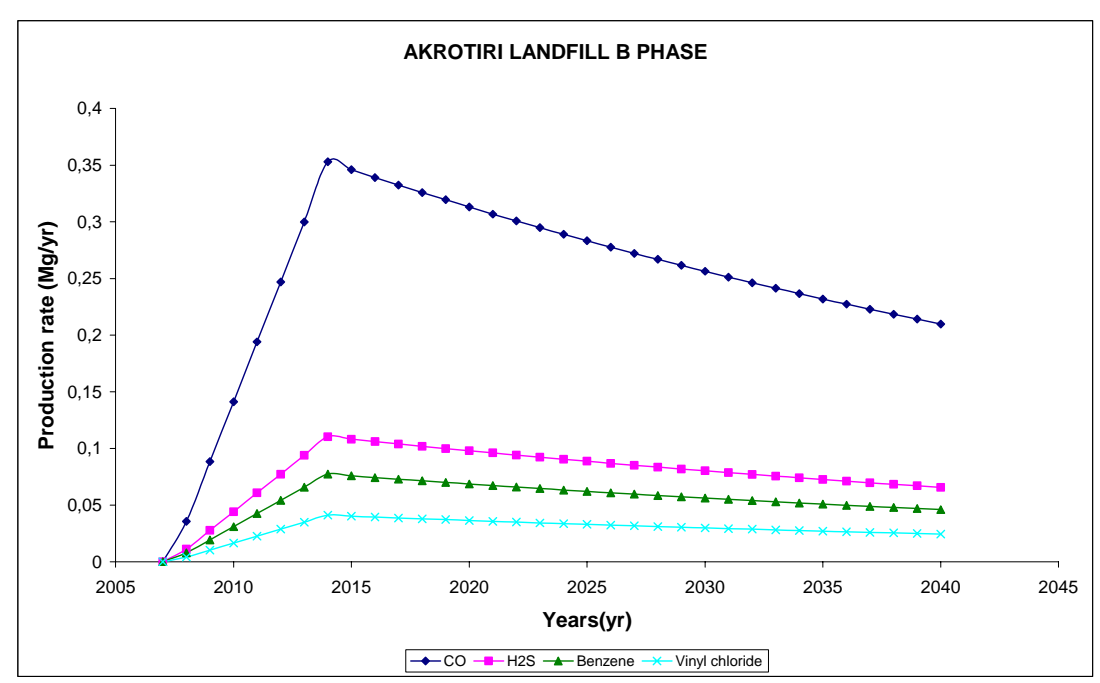

Figure 6. Annual emission rates $\left(\mathrm{Mg} \mathrm{yr}^{-1}\right)$ of $\mathrm{CO}, \mathrm{H}_{2} \mathrm{~S}$, benzene and vinyl chloride for the Akrotiri landfill B phase (2007-2013)

Finally figures 7-8 present the annual emission rates of NMOC for the landfill A and B phases respectively. The maximum emission rate of $\mathrm{NMOC}$ is $11.27 \mathrm{Mg} \mathrm{yr}^{-1}$ for the landfill $\mathrm{A}$ phase, while for the landfill B phase the maximum emission rate of NMOC is $18.62 \mathrm{Mg} \mathrm{yr}^{-1}$. NMOC are contained in the biogas in a small percentage up to $2 \%$ and include various harmful and odor organic air pollutants as HAP and volatile organic components (VOC). Despite their small concentration in the biogas they are emitted in atmosphere causing risk to public health in the general population because of the harmful and toxic gases containing, unpleasant odor in regions adjacent to landfill, atmospheric problems such as photochemical smog and ozone formation due to the photochemical activity of VOC and finally contribute to the greenhouse effect (Fadel et al., 1997). A study by the Environmental Protection Agency (US-EPA) has resulted to the identification of 94 non-methane organic compounds (NMOC) (US EPA 1995).

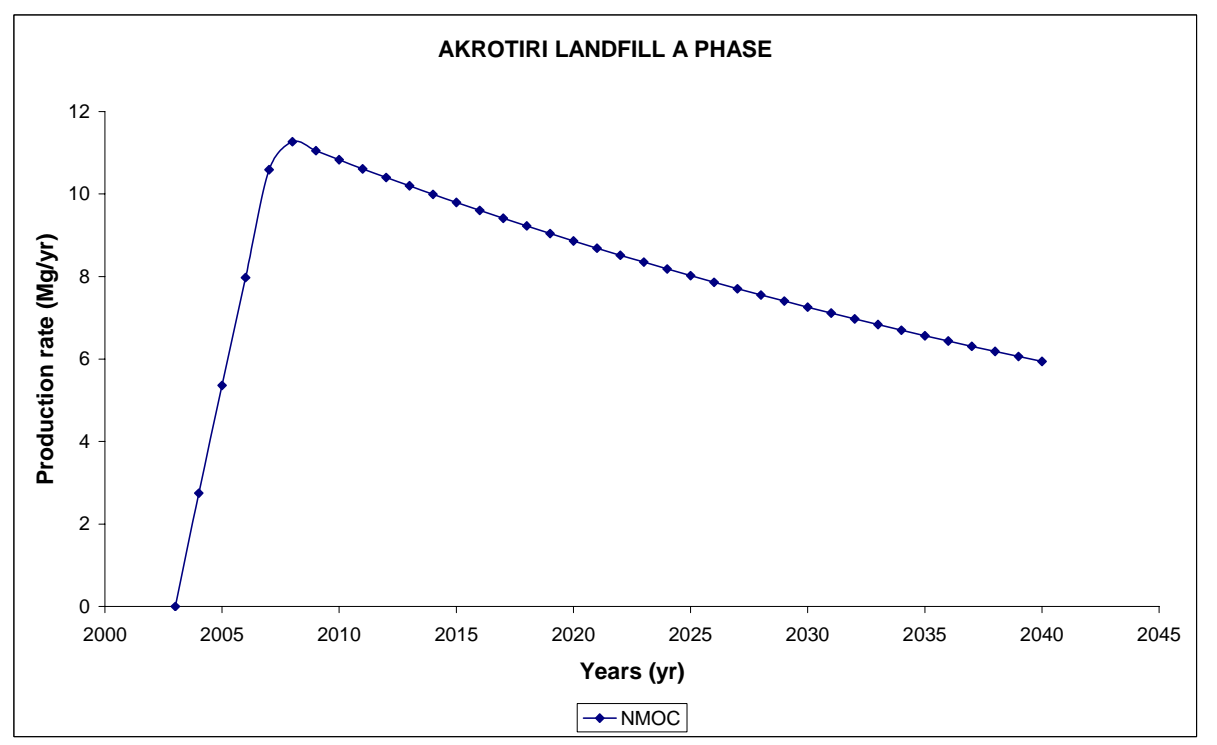

Figure 7. Annual emission rates $\left(\mathrm{Mg} \mathrm{yr}^{-1}\right)$ of $\mathrm{NMOC}$ for the Akrotiri landfill A phase (20032007) 


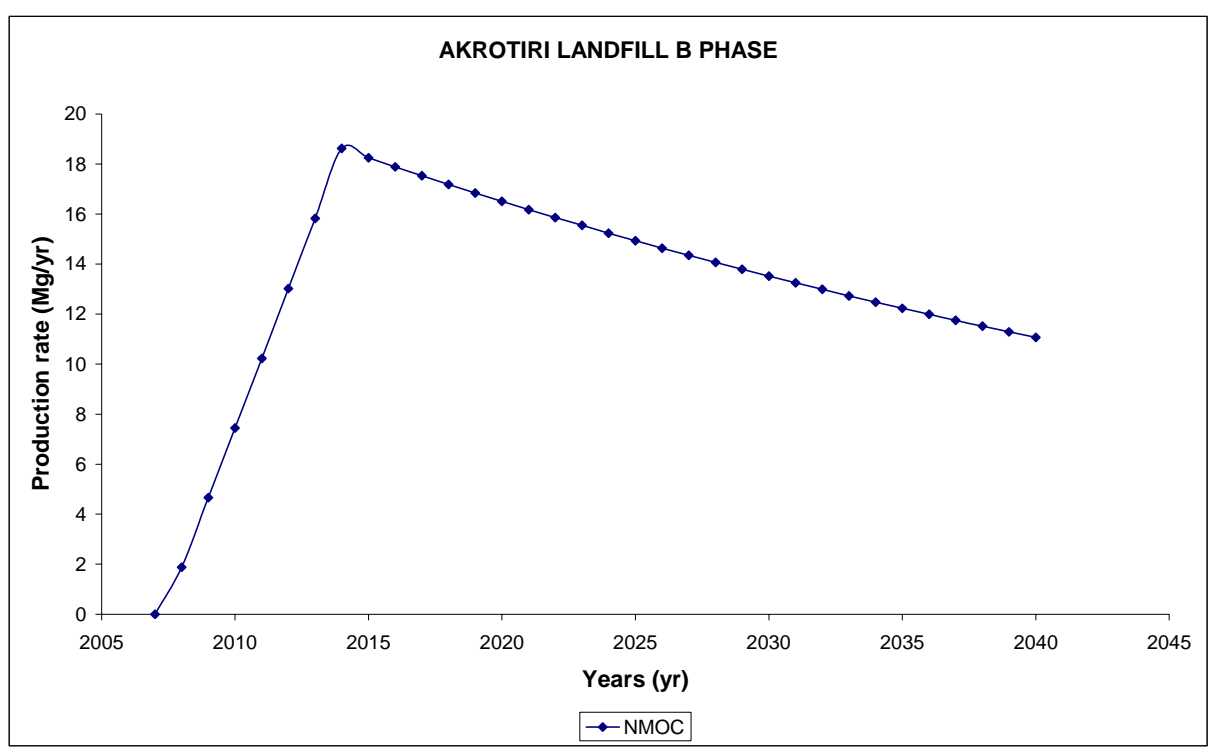

Figure 8. Annual emission rates $\left(\mathrm{Mg} \mathrm{yr}^{-1}\right)$ of NMOC for the Akrotiri landfill B phase (20072013)

According to the official data from the IPCC framework, methane emissions in 2007 from landfills in Greece were $116.64 \mathrm{kt} \mathrm{yr}^{-1}$ while biogas productions in 2002 from the Ano Liosia landfill (Athens) were $301370 \mathrm{Nm}^{3} \mathrm{~d}^{-1}$ and $991.8 \mathrm{~m}^{3} \mathrm{~d}^{-1}$ from the Volos landfill.

\section{CONCLUSIONS}

Three different landfill gas emission models were applied for the estimation of the landfill gas emission rates of the Akrotiri landfill site. The LandGEM model is selected for the determination of more representative assessed landfill gas emission rates and for further dispersion estimations since it is the most reliable model for the quantification of the emission rates (Paraskaki and Lazaridis, 2005). A main weakness of the triangular model is that uses arbitrary values for the determination of the maximum landfill gas yield time and the emission period. In addition, the stoichiometric model provides only rough estimates of the potential gas yield and should only be used in defining maximum attainable yields.

Methane emissions in 2005 from Akrotiri landfill A phase was $0.005354 \mathrm{Mt} \mathrm{CO}_{2}$-eq which represent $0.22 \%$ of total methane emissions released from landfills in Greece $\left(2.4 \mathrm{Mt} \mathrm{CO}_{2}\right.$ eq).

\section{REFERENCES}

Akolkar A.B., Choudhury M.K., Selvi P.K. (2008). Assessment of Methane Emission from Municipal Solid Wastes Disposal Sites, Research Journal of Chemistry and Environment, 12(4), 49-55.

Boltze U. and De-Freitas H.M. (1997). Monitoring Gas Emissions from Landfill Sites, Waste Management and Research, 15, 463-476.

Borjesson G., Sundh I., Svensson B., (2004). Microbial oxidation of $\mathrm{CH} 4$ at different temperatures in landfill cover soils, Federation of European Microbiological Societies, 48, 305-312.

Christensen T., Cossu R., Stegman R. (1989) Sanitary land-filling: Process, Technology and Environmental Impact, Academic Press, London.

Fourie A.B., Morris J.W.F., (2004). Measure gas emissions from four landfills in South Africa and some implications for landfill design and methane recovery in semiarid climates, Waste Management and Research, 22, 440-453.

Gardner N., Manley B.J.W. and Pearson J.M. (1993). Gas Emissions from Landfills and their Contributions to Global Warming, Applied Energy, 44, 165-174.

Halvadakis C.P. (1983). Methanogenesis In Solid Waste Landfill Bioreactors, Ph.D. Dissertation, Stanford University.

Hansen J., (2004). Riscaldamento globale: una bomba da disinnescare. (Global warming: a bomb to be defused). Le Scienze, No. 428, p. 76. 
Humer M., Lechner P., (1999). Alternative approach to the elimination of greenhouse gases from old landfills, Waste Management and Research, 17, 443-452.

IPCC (Intergovernmental Panel on Climate Change), (2006). IPCC Guidelines for National Greenhouse Gas Inventories.

IPCC, (2007a). Summary for policymakers. In: Metz, B., Davidson, O.R., Bosch, P.R., Dave, R., Meyer L.A. (Eds.), Climate Change 2007: Mitigation. Contribution of Working Group III to the Fourth Assessment Report of the Intergovernmental Panel on Climate Change. Cambridge University Press, Cambridge, UK and New York, USA.

IPPC, (2007b). Working Group III Report (WGIII): Climate Change 2007: Mitigation of Climate Change.

Jones H. and Nedwell B.D. (1990). Soil Atmosphere Concentration Profiles and Methane Emission Rates in the Restoration Covers Above Landfill Sites: Equipment and Preliminary Results, Waste Management and Research, 8, 21-31.

Kjeldsen P. and Fischer V.E. (1995). Landfill Gas Migration-Field Investigation at Skellingsted Landfill, Denmark, Waste Management and Research, 13, 467-484.

Lin J.S. and Hildemann L.M. (1995). Nonsteady-state analytical model to predict gaseous emissions of volatile organic compounds from landfills, Journal of hazardous materials, 40 , 271-295.

Lou X.F. and Nair J. (2009). The impact of landfilling and composting on greenhouse gas emissions - A review, Bioresource Technology, 100, 3792-3798.

Mackie K.R. \& Cooper C.D. (2009). Landfill gas emission prediction using Voronoi diagrams and importance sampling, Environmental Modelling \& Software, 24 1223-1232.

Monni S., Pipatti R., Lehtilä A., Savolainen I. and Syri S., (2006). Global climate change mitigation scenarios for solid waste management. Espoo, Technical Research Centre of Finland. VTT Publications, No.603, pp 51.

Papageorgiou A., Barton J.R. and Karagiannidis A. (2009). Assessment of the greenhouse effect impact of technologies used for energy recovery from municipal waste: A case for England, Journal of Environmental Management, 90, 2999-3012.

Paraskaki I. and Lazaridis M. (2005). Quantification of landfill emissions to air: a case study of the Ano Liosia landfill site in the greater Athens area, Waste Management and Research, 23, 199208.

Parker T., Dottridge J. and Kelly S. (2002). Investigation of the Composition and Emissions of Trace Components in Landfill Gas. R\&D Technical Report P1-438/TR. Bristol: Environment Agency.

Ruston L. (2003). Health hazards and waste management, Br Med Bull, 68, 183-197.

Tagaris E, Sotiropoulou REP, Pilinis C, Halvadakis (2003). A methodology to estimate odors around landfill sites: The use of methane as an odor index and its utility in landfill siting, Journal of the Air and Waste Management Association, 53(5), 629-634.

Tchobanoglous G., Theisen H. and Vigil S. (1993). Integrated Solid Waste Management, Engineering Principles and Management Issues, McGraw Hill, New York.

US EPA (1995). Air Emissions from Municipal Solid Waste Landfills- Background Information for Final Standards and Guidelines, Emission Standards Division, (US EPA-453/R-94-021). Office of Air and Radiation, Office of Air Quality Planning and Standards, United States Environmental Protection Agency.

US EPA (2004). Quantification of Exposure: Development of the Emissions Inventory for the Inhalation Risk Assessment (Chapter 7).

US EPA (2005). User's Manual, Landfill Gas Emissions Model, Version, 3.02. (US EPA-600/R05/047), United States Environmental Protection Agency.

US EPA, (2006). Global anthropogenic non-CO2 greenhouse gas emissions: 1990-2020. Office of Atmospheric Programs, Climate Change Division. 